Asian J. Med. Biol. Res. 2021, 7 (1), 56-63; doi: 10.3329/ajmbr.v7i1.53309

\author{
Asian Journal of \\ Medical and Biological Research \\ ISSN 2411-4472 (Print) 2412-5571 (Online) \\ www.ebupress.com/journal/ajmbr
}

\title{
Article \\ Knowledge on integrated management of childhood illness among health and family planning field workers
}

\author{
Mst. Akhtara Khatun ${ }^{1 *}$, Ashees Kumar $\mathrm{Saha}^{2}$, Sabrina Aktar $^{1}$ and Fouzia $\operatorname{Hasin}^{3}$ \\ ${ }^{1}$ Senior Staff Nurse, Rajshahi Medical College Hospital, Rajshahi, Bangladesh \\ ${ }^{2}$ Nursing Officer, Upazilla Health Complex, Bagha, Rajshahi, Bangladesh \\ ${ }^{3}$ Department of Nutrition and Biochemistry, NIPSOM, Mohakhali, Dhaka, Bangladesh \\ *Corresponding author: Mst. Akhtara Khatun, Senior Staff Nurse, Rajshahi Medical College Hospital, Rajshahi, \\ Bangladesh. Phone: +8801723904895; E-mail: inofakhtara@gmail.com
}

Received: 05 March 2021/Accepted: 25 March 2021/ Published: 31 March 2021

\begin{abstract}
Integrated Management of Childhood illness (IMCI) is a strategy for reducing mortality among children under the age of 5 years. This study was aim to assess the level of knowledge on IMCI among health and family planning field worker. Convenience sampling and a semi-structured questionnaire was used to collect data among 237 respondents. Knowledge level was categorised as good, average and poor while association of categorical data were done by Chi squire test. The mean age of participants was $36.03 \pm 10.13$ years where $(82.3 \%)$ respondents were female. The mean duration of job was $11.27 \pm 9.81$ years where $(71.7 \%)$ respondents did not have training on IMCI. Among the respondents, $42.6 \%$ didn't know any of the objectives and $46.8 \%$ respondents knew that one of the components of IMCI, 51.5\% respondents knew that IMCI to improve the health system and $35.3 \%$ respondents knew that IMCI is to improve family and community practice. Signs of diarrhoea in $0-2$ month's old baby was not known by $27.8 \%$ respondents. Majority of the respondents $(72.2 \%)$ had knowledge about increased respiratory rate as a sign of pneumonia. Among the respondents, $42.6 \%$ respondents had poor knowledge regarding IMCI while $28.7 \%$ had well and (28.7\%) had average knowledge. Level of knowledge was significantly associated with age $(p<0.026)$, sex $(p<0.001)$, place of job $(p<0.001)$, designation $(\mathrm{p}<0.001)$, type of job $(\mathrm{p}<0.001)$, duration of Job $(\mathrm{p}<0.001)$, training status $(\mathrm{p}<0.002)$. There are many lacks in the knowledge of health and family planning field workers, they need training on IMCI to prevent the under-five mortality and morbidity.
\end{abstract}

Keywords: knowledge; IMCI; health; family planning; field workers

\section{Introduction}

The Integrated Management of Childhood Illness (IMCI) is a strategy which was developed by the World Health Organization (WHO) and the United Nations International Children's Fund (UNICEF) in 1992 as an integrated approach to improve child health. IMCI is a set of integrated (combined) guidelines, instead of separate guidelines for each illness which can affect a child. Its main objective is the reduction of mortality and morbidity associated with the major causes of childhood illness (Liu et al., 2012). Individual health interventions shown to be effective in reducing child mortality include exclusive breast feeding, improved vaccination coverage, oral rehydration therapy, pneumonia therapy, and early treatment for malaria in endemic areas. However, children presenting to first-level health facilities seldom present with a single ailment. The presence of multiple and overlapping morbidities makes diagnosis and treatment difficult for the healthcare worker. Health care packages that aim to integrate these components of health care strategy have been designed and implemented at community, national, and international levels (Gera et al., 2016).

IMCI includes both preventive and curative elements that are implemented by families and communities as well as by health facilities (WHO, 2019). This strategy includes three main components: (1) improvement in the case 
management skills of health care staff through provision of locally adapted guidelines on IMCI and activities to promote their use; (2) improvement in the overall health care system required for effective management of childhood illnesses; (3) improvement in family and community health care practices (Tulloch, 1999).

In health facilities, the IMCI strategy promotes the accurate identification of childhood illnesses in outpatient settings, ensures appropriate combined treatment of all major illnesses, strengthens the counseling of caretakers, and speeds up the referral of severely ill children. In the home setting, it promotes appropriate care seeking behavior's, improved nutrition and preventative care, and the correct implementation of prescribed care (WHO, 2019). IMCI aims to reduce death, illness and disability, and to promote improved growth and development among children under five years of age and target acute respiratory infections (ARI), diarrhea, measles, malaria and malnutrition, which are the five main causes of childhood deaths (Joshi et al., 2016).

In Bangladesh, health and family planning workers are responsible for the health promotion and detection of signs of diseases (or of the risk of disease) in community level. Government of Bangladesh, trained Health and Family Planning Workers through 11 days IMCI clinical management training (CMT) to provide quality service following IMCI case management protocol (IMCI Newsletter, 2017). Implementation of IMCI is influenced by lack of trained healthcare personnel, insufficient service time, and lack of supervision from office of health, and knowledge and attitude of healthcare personnel's in implementing IMCI after training (Kiplagat $e t$ $a l ., 2014)$. For this, proper knowledge regarding IMCI is essential. Adequate knowledge on IMCI enables health workers making better decision and can led to significant improvements in children's health in Bangladesh.

The study can provide new insight for policy makers to devote resources for achieving the best possible quality of neonatal and under five children's health services. This would further help to reduce the morbidity and mortality rates of under five children and strengthen child health nationwide.

\section{Materials and Methods}

\subsection{Study pattern design}

A cross sectional study was performed using semi-structured interviewer-administered questionnaire at Boalia, Rajpara and Godagari thana of Rajshahi district from $1^{\text {st }}$ January 2019 to $31^{\text {st }}$ December 2019 among the health and family planning workers of the study place where the study was done were the study population.

\subsection{Selection criteria}

Health and family planning workers were selected on the basis of following inclusion and exclusion criteria-

Inclusion criteria: Health and family planning workers having at least six months job experience, both male and female health and family planning workers

Exclusion criteria: Unwilling to participate in the study

\subsection{Sample size}

The following formula was used to calculate the sample size: $\mathrm{n}=\mathrm{z}^{2} \mathrm{pq} / \mathrm{d}^{2}=(1.96)^{2} \times 0.81 \times 0.19 /(0.05)^{2}=237$

\subsection{Data analysis}

After completion of data collection, the data were checked and edited manually and verified before tabulation. Data were coded, entered and analyzed in a computer. The statistical analysis was conducted using SPSS (Statistical Package for Social Science) version 25 statistical software.

\subsection{Ethical consideration}

All the information collected for the study was utilized only for the purpose of thesis and was not disclosed to anyone. Ethical approval was obtained from the ethical committee of NIPSOM, under the Bangabandhu Sheikh Mujib Medical University, Dhaka, Bangladesh. 


\section{Results}

Table 1. Distribution of the respondents by demographic status $(n=237)$.

\begin{tabular}{|c|c|c|c|}
\hline Attributes & Characteristics & Frequency & Percent \\
\hline \multirow{4}{*}{ Age (in years) } & $18-27$ & 59 & 24.9 \\
\hline & $28-37$ & 82 & 34.6 \\
\hline & $38-47$ & 53 & 22.4 \\
\hline & 48 and above & 43 & 18.1 \\
\hline \multirow{2}{*}{ Gender } & Male & 42 & 17.7 \\
\hline & Female & 195 & 82.3 \\
\hline \multirow{3}{*}{ Religion } & Muslims & 225 & 95.0 \\
\hline & Hindu & 6 & 2.5 \\
\hline & Christian & 6 & 2.5 \\
\hline \multirow{7}{*}{$\begin{array}{l}\text { Educational status of } \\
\text { the respondents }\end{array}$} & SSC & 9 & 3.8 \\
\hline & HSC & 55 & 23.2 \\
\hline & Diploma & 76 & 32.1 \\
\hline & Graduate & 31 & 13.1 \\
\hline & BSC nursing/ Public health nursing & 23 & 9.7 \\
\hline & Masters & 38 & 16.0 \\
\hline & Others & 5 & 2.1 \\
\hline \multirow{5}{*}{$\begin{array}{l}\text { Monthly family income } \\
\text { (BDT) }\end{array}$} & Up to 10,000 & 25 & 10.5 \\
\hline & 11,000 to 20,000 & 62 & 26.2 \\
\hline & 21,000 to 30,000 & 55 & 23.2 \\
\hline & 31,000 to 40,000 & 32 & 13.5 \\
\hline & Above 40,000 & 63 & 26.6 \\
\hline
\end{tabular}

Above Table 1 shows that about one fourth of the respondents $(24.9 \%)$ were from 18-27years age group whereas one third (34.6\%) were from 28-37 years age group and the mean age of participants was $36.03 \pm 10.13$ years which ranged from $18-58$ years. Large number (82.3\%) respondents were female and $17.7 \%$ were male. Most of the respondents (94.9\%) were Muslims and others were Hindus 2.5\% $(\mathrm{n}=6)$ and Christians $(2.5 \%)$. Of the respondents $(32.1 \%)$ were diploma passed and $(23.2 \%)$ of the respondents had passed HSC. Among them, (3.8\%) had passed SSC, (13.1\%) were graduate and (16.0\%) had master's degree. Of the respondents (10.5\%) had monthly income of up to TK $10,000,(26.2 \%)$ from TK 11,000 to $20,000,(23.2 \%)$ respondents had monthly income from TK 21,000 to $30,000,(13.5 \%)$ respondents had from TK 31,000 to 40,000 and $(26.6 \%)$ had monthly income more than TK 40,000.The mean monthly family income of the respondents was TK 33037.97 \pm 20649.28 which ranged from 5,000 to $100,000 \mathrm{TK}$.

Table 2. Distribution of the respondents by job related attributes $(n=237)$.

\begin{tabular}{|l|l|l|}
\hline Attributes & Characteristics & Frequency (\%) \\
\hline \multirow{4}{*}{ Place of job } & Village & $121(51.1 \%)$ \\
\cline { 2 - 3 } & City & $116(48.9 \%)$ \\
\hline \multirow{4}{*}{ Designation } & Health assistants (HA) & $89(37.6 \%)$ \\
\cline { 2 - 3 } & Nurse & $76(32.1 \%)$ \\
\cline { 2 - 3 } & Family Welfare Visitors (FWV) & $45(19.0 \%)$ \\
\cline { 2 - 3 } & Sub Assistant Community Medical Officers (SACMO) & $27(11.4 \%)$ \\
\hline \multirow{4}{*}{$\begin{array}{l}\text { Dype of job } \\
\text { (in years) }\end{array}$} & Government & $151(63.7 \%)$ \\
\cline { 2 - 3 } & Private & $86(36.3 \%)$ \\
\cline { 2 - 3 } & Up to 4 & $86(36.3 \%)$ \\
\cline { 2 - 3 } & $5-9$ & $47(19.8 \%)$ \\
\cline { 2 - 3 } & $10-14$ & $16(6.8 \%)$ \\
\cline { 2 - 3 } & $15-19$ & $28(11.8 \%)$ \\
\cline { 2 - 3 } & $20-24$ & $25(10.5 \%)$ \\
\hline
\end{tabular}

In Table 2 shows that $48.9 \%$ respondents were working in cities and (51.1\%) were working in villages. Of the respondents $(37.6 \%)$ were $\mathrm{HA},(32.1 \%)$ were nurses, $(19.0 \%)$ were FWV and (11.4\%) were (SACMO). 
Maximum (63.7\%) respondents worked for Government and (36.3\%) worked in private. The job duration of the respondents. (36.3\%) up to 4 years, (19.8\%) had 5-9 years, $(6.8 \%)$ respondents $10-14$ years, $(11.8 \%)$ of the respondents had 15-19 years, (10.5\%) respondents had 20-24 years and (14.8\%) respondents had more than 24 years job experience. The mean duration of job was $11.27( \pm 9.81)$ years which ranged from 6 months to 37 years.

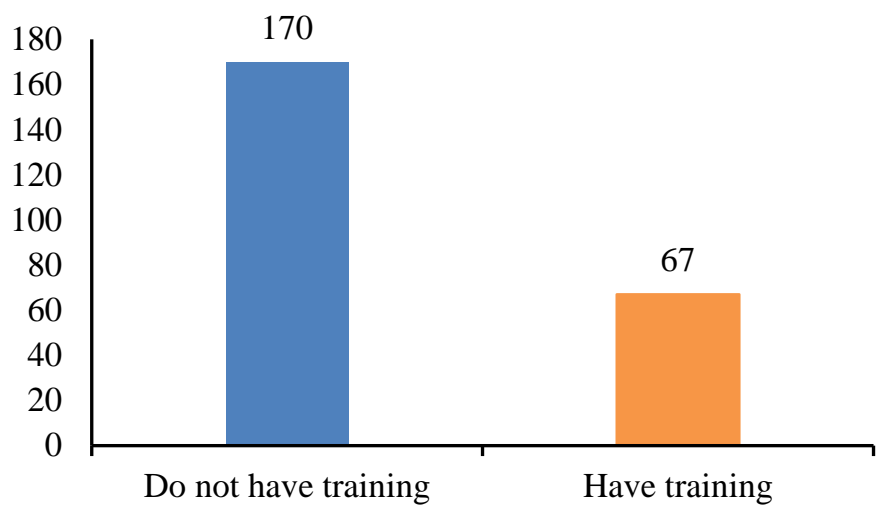

Figure 1. Distribution of the respondents by training on IMCI $(n=237)$.

In Figure 1 shows that $71.7 \%(\mathrm{n}=170)$ respondents did not have training on IMCI while $28.3 \%(67)$ had training on IMCI.

Table 3. Distribution of the respondents by knowledge $(n=237)$.

\begin{tabular}{|c|c|c|}
\hline Attributes & Characteristics & Frequency $(\%)$ \\
\hline \multirow{3}{*}{$\begin{array}{l}\text { Knowledge } \\
\text { regarding } \\
\text { objectives }\end{array}$} & To reduce morbidity and mortality of under five children & $91(38.4 \%)$ \\
\hline & $\begin{array}{l}\text { To promote growth and development of child through counseling the } \\
\text { mothers and caretakers }\end{array}$ & $114(48.1 \%)$ \\
\hline & Do not know & $101(42.6 \%)$ \\
\hline \multirow{5}{*}{$\begin{array}{l}\text { Knowledge } \\
\text { regarding } \\
\text { components }\end{array}$} & To reduce morbidity and mortality of under five children & $91(38.4 \%)$ \\
\hline & Improving case management skills of health workers & $111(46.8 \%)$ \\
\hline & Improving the health system & $122(51.5 \%)$ \\
\hline & Improving family and community practice & $79(33.3 \%)$ \\
\hline & Do not know & $3(1.3 \%)$ \\
\hline \multirow{5}{*}{$\begin{array}{l}\text { Examination of } \\
\text { diarrhea }\end{array}$} & Examination of eyes & $164(69.2 \%)$ \\
\hline & Skin pinch & $151(63.7 \%)$ \\
\hline & General condition of the Baby & $106(44.7 \%)$ \\
\hline & Level of consciousness & $69(29.1 \%)$ \\
\hline & Do not know & $66(27.8 \%)$ \\
\hline \multirow{5}{*}{$\begin{array}{l}\text { Clinical } \\
\text { features of } \\
\text { pneumonia }\end{array}$} & Increased respiratory rate & $171(72.2 \%)$ \\
\hline & In-drawing of chest & $149(62.9 \%)$ \\
\hline & Breathlessness & $147(62.0 \%)$ \\
\hline & Cough & $106(44.7 \%)$ \\
\hline & Do not know & $57(24.1 \%)$ \\
\hline \multirow{4}{*}{$\begin{array}{l}\text { Clinical } \\
\text { features of } \\
\text { malaria }\end{array}$} & Fever & $149(62.9 \%)$ \\
\hline & Shivering & $132(55.7 \%)$ \\
\hline & Vomiting & $63(26.6 \%)$ \\
\hline & Do not know & $60(25.3 \%)$ \\
\hline \multirow{4}{*}{$\begin{array}{l}\text { Vitamin A } \\
\text { deficiency }\end{array}$} & Difficult in vision in dim light & $176(74.3 \%)$ \\
\hline & Dry cornea & $61(25.7 \%)$ \\
\hline & Dry skin & $59(24.9 \%)$ \\
\hline & Do not know & $59(24.9 \%)$ \\
\hline \multirow{5}{*}{$\begin{array}{l}\text { Diagnose of } \\
\text { anemia }\end{array}$} & Examination of palm of the hand & $154(65.0 \%)$ \\
\hline & Examination of nail bed & $118(49.8 \%)$ \\
\hline & Examination of tongue & $113(47.7 \%)$ \\
\hline & Examination of conjunctiva & $62(26.2 \%)$ \\
\hline & Do not know & $64(27.0 \%)$ \\
\hline
\end{tabular}


In Table 3 represents respondent's knowledge. Knowledge regarding objectives, highest (38.4\%) was to reduce morbidity and mortality of under five children. Knowledge regarding components highest (38.4\%) was to reduce morbidity and mortality of under five children. Examination of diarrhea (69.2\%) knowledge was Examination of eyes. Clinical features of pneumonia (72.2\%) knowledge was increased respiratory rate. Clinical features of malaria (62.9\%) knowledge was Fever. Vitamin A deficiency (74.3\%) knowledge was difficult in vision in dim light. Diagnose of anemia $(65.0 \%)$ knowledge was examination of palm of the hand.

Table 4. Distribution of the respondents by knowledge ( $n=237)$.

\begin{tabular}{|c|c|c|}
\hline Attributes & Characteristics & Frequency $(\%)$ \\
\hline \multirow{4}{*}{$\begin{array}{l}\text { Examination of child with } \\
\text { malnutrition }\end{array}$} & Examination for palm of the hand & $160(67.5 \%)$ \\
\hline & Assess degree of malnutrition from growth chart & $138(58.2 \%)$ \\
\hline & Examination for ankle Edema & $47(19.8 \%)$ \\
\hline & Do not know & $66(27.8 \%)$ \\
\hline \multirow{5}{*}{ Signs of severe dehydration } & Sunken eyes & $174(73.4 \%)$ \\
\hline & Loss of skin tone & $157(66.2 \%)$ \\
\hline & Unconsciousness & $143(60.3 \%)$ \\
\hline & Lethargy & $91(38.4 \%)$ \\
\hline & Do not know & $60(25.3 \%)$ \\
\hline \multirow{4}{*}{$\begin{array}{l}\text { Observation of a } 0-2 \text { month old } \\
\text { baby who has difficulty during } \\
\text { breast feeding }\end{array}$} & Physical attachment of the baby with mother & $130(54.9 \%)$ \\
\hline & Sucking capacity of baby & $124(52.3 \%)$ \\
\hline & General condition of the baby & $99(41.8 \%)$ \\
\hline & Do not know & $100(42.2 \%)$ \\
\hline \multirow{4}{*}{$\begin{array}{l}\text { Give Vitamin A supplement to } \\
\text { a child }\end{array}$} & Persistent diarrhea (>14 days) & $128(54.0 \%)$ \\
\hline & Severe malnutrition & $102(43.0 \%)$ \\
\hline & Measles & $69(29.1 \%)$ \\
\hline & Do not know & $144(60.8 \%)$ \\
\hline \multirow{6}{*}{$\begin{array}{l}\text { Danger signs for childhood } \\
\text { illness }\end{array}$} & Convulsion & $162(68.4 \%)$ \\
\hline & Unconsciousness & $161(67.9 \%)$ \\
\hline & Severe vomiting & $131(55.3 \%)$ \\
\hline & Lethargy & $129(54.4 \%)$ \\
\hline & Unable to drink & $113(47.7 \%)$ \\
\hline & Do not know & $62(26.2 \%)$ \\
\hline \multirow{9}{*}{ Vaccine preventable disease } & Tuberculosis & $236(99.6 \%)$ \\
\hline & Polio & $236(99.6 \%)$ \\
\hline & Tetanus & $236(99.6 \%)$ \\
\hline & Measles & $235(99.2 \%)$ \\
\hline & Rubella & $233(98.3 \%)$ \\
\hline & Diphtheria & $231(97.5 \%)$ \\
\hline & Hepatitis & $231(97.5 \%)$ \\
\hline & Whooping cough & $230(97.0 \%)$ \\
\hline & Mumps & $85(35.9 \%)$ \\
\hline
\end{tabular}

In Table 4 represents respondent's knowledge. Knowledge regarding examination of child with malnutrition, highest (67.5\%) knowledge was examination for palm of the hand. Signs of severe dehydration (73.4\%) knowledge was sunken eyes. Observation of a 0-2 month old baby who has difficulty during breast feeding (54.9\%) knowledge was physical attachment of the baby with mother. Give Vitamin A supplement to a child (54.0\%) knowledge was persistent diarrhea (>14 days). Danger signs for childhood illness (68.4\%) knowledge was convulsion. Vaccine preventable disease (99.6\%) knowledge was tuberculosis, polio and tetanus. 


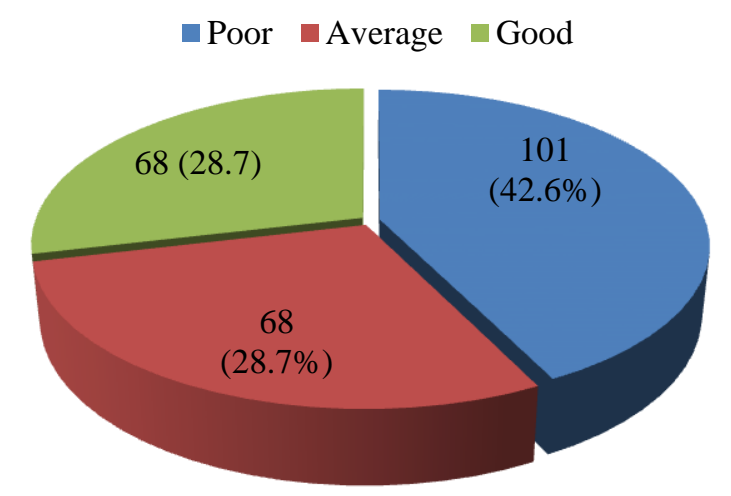

Figure 2. Distribution of the respondents by level of knowledge regarding IMCI $(n=237)$.

In Figure 2 shows that $42.6 \%(\mathrm{n}=101)$ respondents had poor knowledge regarding IMCI while $28.7 \%(\mathrm{n}=68)$ had good and $28.7 \%(n=68)$ had average knowledge.

Table 5. Association between demographic attributes and knowledge regarding IMCI of the respondents $(\mathbf{n}=\mathbf{2 3 7})$.

\begin{tabular}{|c|c|c|c|c|c|c|}
\hline \multirow[b]{2}{*}{ Attributes } & \multirow[b]{2}{*}{ Characteristics } & \multicolumn{4}{|c|}{ Level of knowledge } & \multirow[b]{2}{*}{ Statistics } \\
\hline & & $\begin{array}{l}\text { Poor } \\
\text { f }(\%)\end{array}$ & $\begin{array}{l}\text { Average } \\
\text { f }(\%)\end{array}$ & $\begin{array}{l}\text { Good } \\
\text { f }(\%)\end{array}$ & $\begin{array}{l}\text { Total } \\
\text { f }(\%)\end{array}$ & \\
\hline \multirow{3}{*}{$\begin{array}{l}\text { Age } \\
\text { (in years) }\end{array}$} & $18-27$ & $30(50.8)$ & 11 (18.6) & $18(30.5)$ & $59(100.0)$ & \multirow{3}{*}{$\begin{array}{l}\chi^{2}=11.02 \\
\mathrm{df}=4 \\
\mathrm{p}=0.026\end{array}$} \\
\hline & $28-37$ & $41(50.0)$ & $24(29.3)$ & $17(20.7)$ & $82(100.0)$ & \\
\hline & 38 and above & $30(31.3)$ & $33(34.4)$ & $33(34.4)$ & $96(100.0)$ & \\
\hline \multirow{2}{*}{ Sex } & Male & $15(35.7)$ & $22(52.3)$ & $5(11.9)$ & $42(100.0)$ & \multirow{2}{*}{$\begin{array}{l}\chi^{2}=15.56 \\
\mathrm{df}=2 \\
\mathrm{p}<0.001\end{array}$} \\
\hline & Female & $86(44.1)$ & 46 (23.6) & $63(32.3)$ & $195(100)$ & \\
\hline \multirow{4}{*}{ Designation } & Nurse & $28(36.8)$ & $19(25.0)$ & $29(38.2)$ & $76(100.0)$ & \multirow{4}{*}{$\begin{array}{l}\chi 2=30.08 \\
d f=6 \\
p<0.001\end{array}$} \\
\hline & SACMO & $15(55.6)$ & $6(22.2)$ & $6(22.2)$ & $27(100.0)$ & \\
\hline & FWV & $11(24.4)$ & $11(24.4)$ & $23(51.1)$ & $45(100.0)$ & \\
\hline & HA & $47(52.8)$ & $32(36.0)$ & $10(11.2)$ & $89(100.0)$ & \\
\hline \multirow{3}{*}{$\begin{array}{l}\text { Duration of job } \\
\text { (in years) }\end{array}$} & Up to 4 & $51(59.3)$ & $16(18.6)$ & $19(22.1)$ & $86(100.0)$ & \multirow{3}{*}{$\begin{array}{l}\chi 2=21.47 \\
d f=4 \\
p<0.001\end{array}$} \\
\hline & 5 to 14 & $28(44.4)$ & $19(30.2)$ & $16(25.4)$ & $63(100.0)$ & \\
\hline & $>14$ years & $22(25.0)$ & $33(37.5)$ & $33(37.5)$ & $88(100.0)$ & \\
\hline \multirow{2}{*}{$\begin{array}{l}\text { Training on } \\
\text { IMCI }\end{array}$} & No training & $81(47.6)$ & $51(30.0)$ & $38(22.4)$ & $170(100.0)$ & \multirow{2}{*}{$\begin{array}{l}\chi^{2}=12.35 \\
\mathrm{df}=2 \\
\mathrm{p}=0.002\end{array}$} \\
\hline & Have training & $20(29.9)$ & $17(25.4)$ & $30(44.8)$ & $67(100.0)$ & \\
\hline \multirow{2}{*}{ Place of job } & City & $62(53.4)$ & $18(15.5)$ & $36(31.0)$ & $116(100.0)$ & \multirow{2}{*}{$\begin{array}{l}\chi^{2}=20.43 \\
d f=2 \\
p<0.001\end{array}$} \\
\hline & Village & $39(32.2)$ & $50(41.3)$ & $32(26.4)$ & $121(100.0)$ & \\
\hline \multirow[t]{2}{*}{ Type of job } & Government & $43(28.5)$ & $56(37.1)$ & $52(34.4)$ & $151(100.0)$ & \multirow{2}{*}{$\begin{array}{l}\chi 2=34.52 \\
d f=2 \\
p<0.001\end{array}$} \\
\hline & Private & $58(67.4)$ & $12(14.0)$ & $16(18.6)$ & $86(100.0)$ & \\
\hline \multirow{3}{*}{$\begin{array}{l}\text { Educational } \\
\text { status }\end{array}$} & Up to HSC & $32(50.0)$ & $12(18.8)$ & $20(31.3)$ & $64(100.0)$ & \multirow{3}{*}{$\begin{array}{l}\chi^{2}=7.28 \\
d f=4 \\
p=0.122\end{array}$} \\
\hline & Diploma & $35(46.1)$ & $20(26.3)$ & $21(27.6)$ & $76(100.0)$ & \\
\hline & Others & $34(35.1)$ & $36(37.1)$ & $27(27.8)$ & $97(100.0)$ & \\
\hline
\end{tabular}

In Table 5 shows that there was significant statistical difference between respondent's age $p<0.026$, sex $\mathrm{p}<0.001$, designation $\mathrm{p}<0.001$, duration of job $\mathrm{p}<0.001$, training on IMCI $\mathrm{p}<0.002$, place of job $\mathrm{p}<0.001$, type of job $p<0.001$ and level of knowledge. There is no association found on educational status and level of knowledge $\mathrm{p}<0.122$.

\section{Discussion}

This cross sectional study found that the mean age of participants was $36.03 \pm 10.13$ ) years which ranged from 18-58 years. Majority of the respondents were less than 37 years of age. A quantitative descriptive study was 
conducted in Timur to assess health workers' knowledge on IMCI where they also found that (54.3\%) were aged less than 35 years (Zulaikha et al., 2018). In this study, (82.3\%) respondents were female and rests (17.7\%) were male which was consistent with the study of Zulaikha et al. (2018). In Bangladesh, (90\%) seats were reserved for female students in nursing profession. Majority of the respondents $(63.7 \%)$ of the present study were working for Government of Bangladesh and rests (36.3\%) worked in private organizations. The Government of Bangladesh implement IMCI in collaboration with other private organizations. World Health Organization provides technical and financial assistance to the Ministry of Health and Family Welfare for implementing the IMCI program. Various other development partners and NGOs also collaborate with the Government.

Out of the 237 respondents, $71.7 \%$ did not have training on IMCI. The Government of Bangladesh provide IMCI training to doctors, SACMOs, nurses, Family welfare visitors. Health Assistant are not included in the training program. For this reason, numbers of the respondents without training were more. Diarrhea is a common problem for under five children in Bangladesh. Health and Family Planning Workers were asked about the examination of diarrhea. One fourth of the workers did not know how to examine a 0-2 month's old baby suffering from diarrhea. Majority of the respondents knew that their eyes should be examined and skin should be pinched. Study of Joshi et al. (2016) reported that 55.5\% respondents had no knowledge regarding this issue. Malnutrition in Bangladesh are the highest in the world. More than 54\% of preschool- children are stunted, 56\% are underweight and more than $17 \%$ are wasted (FAO, 2010). Malnutrition can be assessed easily with the help of growth chart. Out of 237 respondents, $58.2 \%$ had knowledge about growth chart. One fifth knew that one should examine for ankle edema in a 2 months old baby to examine malnutrition. Respondents of India also lack knowledge regarding this issue Joshi et al., 2016). Majority of the Health and Family Welfare Visitors knew that sunken eyes, loss of skin tone, unconsciousness are the signs of severe dehydration. This result is comparable with other studies. Study in Namibia reported $61.5 \%$, in Kenya $41.9 \%$, in Tanzania $42.2 \%$ and in Uganda $62.1 \%$ health workers had knowledge regarding signs of severe dehydration (Krüger et al., 2017).

Breastfeeding is an unequalled way of providing ideal food for the healthy growth and development of infants; it is also an integral part of the reproductive process with important implications for the health of mothers (WHO, 2019). For adequate breast feeding, proper attachment is necessary. Majority of the Health and Family Welfare Visitors had adequate knowledge about this. The current study revealed that $42.6 \%$ health and family planning workers had poor knowledge regarding IMCI while others had good (28.7\%) and average (28.7\%) knowledge. Study conducted in Timur found that majority of respondents $(73.9 \%)$ had sufficient knowledge on IMCI (Zulaikha et al., 2018). The dissimilarity of result might be due to the fact that the study of Zulaikha et al. (2018) was done among health personnel where doctors were included while in the present study did not include any doctors in the study. Older respondents had significantly better knowledge than youngers. This was influenced by respondent's education level which support them to have good level of knowledge. Again, older respondents had the opportunity to acquire knowledge from their job experience. Person from high socioeconomic class get more opportunity to get more education and come in contact with mass media. Theses helps them to get many information. For this reason, respondent having more monthly income had better knowledge than respondent having less monthly income.

Nurses had significantly better knowledge than others. Nurses and SACMOs were more educated than others. Health Assistants workers had the lowest level of education. Most of them were SSC passed. More educational attainment helps people to acquire more knowledge. This result was consistent with another study Joshi et al. (2016). Respondents who were doing government service had significantly better knowledge than others. Respondents having job experience less than 5 years had significantly poor knowledge than others. Job experience enables a person to have more knowledge. Significant better knowledge was observed among respondents who had training. This fact in obvious. Through training a person can get appropriate knowledge. This was in accordance with a study by Rakha et al. (2014) which stated that healthcare personnel who attend IMCI training had sufficient level of knowledge compared to personnel who did not attend IMCI training.

\section{Conclusions}

It was found in the present study found that all most half of the respondents had poor knowledge regarding IMCI while nearly one third had good knowledge. Level of knowledge is associated with age, gender, monthly family income, place of job, designation, type of job, duration of job and training on IMCI.IMCI training can improve the knowledge of the health workers. It is important to increase the knowledge of health and family planning field workers through proper training and supervision. Considering the average level of knowledge regarding IMCI, the following recommendations are put forward: All health and family planning field workers 
should be trained on Integrated Management of Childhood Illness (IMCI). Further research work should be done on large scale.

\section{Conflict of interest}

None to declare.

\section{References}

FAO, 2010. Nutrition country profile Bangladesh. Available at: http://www.fao.org/ag/agn/nutrition/ bgd_en.stm

Gera T, D Shah, P Garner, M Richardson, and HS Sachdev, 2016. Integrated management of childhood illness (IMCI) strategy for children under five. Cochrane Database of Systematic Reviews, 6.

IMCI Newsletter, 2017. Performance report for January to December 2016. Information System (MIS), Directorate General of Health Services (DGHS).

Joshi KJ, HT Koringa, KM Sochaliya and GP Kartha, 2016. A study on knowledge regarding integrated management of neonatal and childhood illness among trained anganwadi workers of Surendranagar district, Gujarat, India. IJCMPH, 3:581-585.

Kiplagat A, R Musto, D Mwizamholya and D Morona, 2014. Factors influencing the implementation of integrated management of childhood illness (IMCI) by healthcare workers at public health centers and dispensaries in Mwanza, Tanzania. BMC public health, 14: 277.

Krüger C, M Heinzel-Gutenbrunner, and M Ali, 2017. Adherence to the integrated management of childhood illness guidelines in Namibia, Kenya, Tanzania and Uganda: evidence from the national service provision assessment surveys. BMC Health Serv. Res., 17: 822.

Liu L, HL Johnson, S Cousens, J Perin, S Scott, JE Lawn, I Rudan, H Campbell, R Cibulskis, M Li and C Mathers, 2012. Global, regional, and national causes of child mortality: an updated systematic analysis for 2010 with time trends since 2000. Lancet, 379: 2151-2161.

Rakha MA, ANM Abdelmoneim, S Farhoud, S Pièche, S Cousens, B Daelmans, and R Bahl, 2014. Does Implementation of the IMCI Strategy Have an Impact on Child Mortality? A Retrospective Analysis of Routine Data from Egypt. BMJ Open, 2013: 1-10.

Tulloch J, 1999. Integrated approach to child health in developing countries. Lancet, 354: SII16-SII20.

WHO, (2019). Integrated Management of Childhood Illness (IMCI). Available at: https://www.who.int/maternal_child_adolescent/topics/child/imci/en/[Retrieved on November 2019].

Zulaikha F, R Triasih and P Purwanta, 2018. Knowledge and Implementation of Integrated Management of Childhood Illness at East Kalimantan. KEMAS: Journal Kesehatan Masyarakat, 14: 163-171. 